\title{
Application of sonicated extracts of cyanobacteria and microalgae for the mitigation of bacterial canker in tomato seedlings
}

\author{
A. J. Toribio' ${ }^{1}$ M. M. Jurado ${ }^{1}$ - F. Suárez-Estrella ${ }^{1}$ J. A. López-González ${ }^{1} \cdot$ M. R. Martínez-Gallardo ${ }^{1}$ M. J. López ${ }^{1}$
}

Received: 11 May 2021 / Revised and accepted: 18 August 2021 / Published online: 28 September 2021

(c) The Author(s) 2021

\begin{abstract}
Microalgae and cyanobacteria could play an important role in crop protection, since they produce bioactive substances that promote plant growth and/or trigger the plant resistance mechanisms. The present study focuses on the control of bacterial canker caused by Clavibacter michiganensis subsp. michiganensis on tomato plants by using sonicated extracts from cyanobacteria and microalgae of the genera Leptolyngbya, Nostoc, Chlorella, and Scenedesmus. For the development of this study, 8 strains were firstly tested for their capacity to inhibit the growth of $C$. michiganensis subsp. michiganensis in vitro, as well as to produce cytokinins and salicylic acid. In order to discard those more phytotoxic strains, the germination index was also estimated in watercress seeds. Scenedesmus-677 and Leptolyngbya-1267 strains were selected in this first phase based on their pesticide and phytostimulant capacity in vitro. Subsequent bioassays on tomato seedlings showed that root application of Scenedesmus-677 could be more aimed at controlling the disease caused by C. michiganensis subsp. michiganensis, while foliar and root application of Leptolyngbya-1267 seems to be more related to the strengthening of the plant through the salicylic acid route. These preliminary results could serve as the basis for a deeper characterization of the biopesticidal and biostimulant effect of both strains, as well as to reveal the benefits derived from the combination of both capacities.
\end{abstract}

Keywords Cyanobacteria $\cdot$ Microalgae $\cdot$ Biopesticide $\cdot$ Biostimulant $\cdot$ Clavibacter michiganensis subsp. michiganensis . Phytohormones

\section{Introduction}

Plant diseases are an important threat to many agricultural and horticultural crops. However, the indiscriminate use of pesticides and synthetic fertilizers during decades has caused serious problems to human and animal health and the environment. These include the reduction of soil fertility, the increase in the solubility of toxic heavy metals, and the development of new pathogens that devastate crops and cause enormous economic losses worldwide (Kumar and Verma 2013; Raymaekers et al. 2020). Considering that the use of soil fumigants is being restricted in Europe and other areas of the world, alternative methods for plant pathogen control are needed (Termorshuizen et al. 2006).

F. Suárez-Estrella

fsuarez@ual.es

1 Department of Biology and Geology, CITE II-B, University of Almería, Agrifood Campus of International Excellence, ceiA3, CIAIMBITAL, 04120 Almeria, Spain
In this last scenario, the damage caused by the bacterium Clavibacter michiganensis subsp. michiganensis, responsible for the bacterial canker in tomatoes (Lycopersicon esculentum), should be highlighted. The main host of economic importance for that pathogen is tomato but natural infection also has been reported on Capsicum annиum (Latin et al. 1995). Clavibacter michiganensis subsp. michiganensis is an aerobic, non-motile, Gram-positive, non-sporing, curved rod that is internationally considered a quarantine organism worldwide distributed (EPPO 2016). Infection of the plant by this bacterium occurs by the entry of the pathogen through natural openings or wounds in roots, stems, and leaves (Nandi et al. 2018). The symptoms described so far are variable and influenced by plant age, cultivar type, and environmental factors. In the field, the first symptom is desiccation of the edge of the leaflets. The plant slowly desiccates, with or without exhibiting wilting (Gleason et al. 1991). Under greenhouse conditions, the first symptom is a reversible wilting of leaves during hot weather, later becoming irreversible. The whole plant then desiccates. Leaves may show white interveinal areas, turning 
brown and necrotic generally before wilt symptoms appear (Gitaitis et al. 1991). Unilateral wilting or withering of leaflets on one side of the leaf, and bird's eye-spot lesions on the fruit surface are the outstanding features for diagnosis of tomato bacterial canker. In advanced infection, vascular discoloration is seen as brown streaks on the stem and petiole. Once it is detected, chemical control is practically impossible. Moreover, there are no hybrids or tomato cultivars with acceptable genetic resistance on the market against $C$. michiganensis subsp. michiganensis. This could be due to the genetic complexity and the genomic instability of this microorganism, the micro-evolutionary changes in the host-pathogen system, as well as the emergence of highly resistant biotypes derived from the continued use of large amounts of chemical pesticides (Khaliluev and Shpakovskii 2013). Therefore, prevention is the most effective control of bacterial canker, based on the reduction of the inoculum and the use of healthy seeds and seedlings (De León et al. 2011; EFSA 2014).

Biological control of plant diseases is the suppression of plant pathogens populations by living organisms (Heimpel and Mills 2017; Lenteren et al. 2018). In this sense, biological control constitutes an excellent alternative or complement to agrochemicals for disease management, since it aims to reduce the density or activity of the pathogen causing the disease, by enhancing one or several autochthonous biological antagonists, or by introducing or inoculating strains previously described as biological control agents. In addition, these agents can provide an extra benefit for the plant, improving growth and development and even inducing resistance mechanisms in the plant itself (Köhl et al. 2019).

Regarding bacterial canker of tomato, several Plant Growth Promoting Rhizobacteria (PGPR) having antagonistic activities towards $C$. michiganensis subsp. michiganensis have been isolated and studied (Deng et al. 2015; Aksoy et al. 2017). Thereby, seed treatments with both Pseudomonas and Bacillus strains improved the tomato plant quality and notably decreased the bacterial canker incidence in field studies (Umesha 2006; Kasselaki et al. 2011).

Today, manufacturers and researchers have paid special attention to the biotechnological applications of microalgae and cyanobacteria. The great diversity and plasticity of these microorganisms make them a good potential source of high-value bioactive compounds. In recent years, cyanobacteria and microalgae have attained great importance due to the fact that they have not only been classified as beneficial bio-agents based on their capability to produce biomass for biofuels, food supplements, and bio-fertilizers for safe agriculture, but also for their role in regulating plant productivity (Singh et al. 2016). Among the most interesting applications of algae and cyanobacteria are their antimicrobial properties, their fertilizer capacity, and their use as food preservatives (Mendiola et al. 2007; Alsenani et al. 2020). These type of microorganisms not only do not compete negatively with the microbiota associated with the plant-soil system, but also potentially favor the beneficial activity attributed especially to the rhizo-microbiota, in addition to improving soil fertility, seed germination, plant growth, nutritional value, and crop yield (Renuka et al. 2018). Some bioactive compounds produced by them are represented by siderophores, alkaloids, amides, fatty acids, and indoles, or antifungal, antiviral, and antibacterial substances such as lipopeptides and polyketides (Singh et al. 2017; Meena et al. 2017).

The control of plant pathogens through the application of commercial products based on microalgae and cyanobacteria is still in a very preliminary stage (Singh et al. 2016). However, the potential of these microorganisms denotes the interest of researchers in continuing to deepen this path. Photosynthetic microbes have the advantage of being organisms with minimal nutritional requirements and rapid growth rates (Herrero and Flores 2008). Along with having a multitude of adaptations to extreme situations, especially in the case of cyanobacteria, that allow them to be competitive against high temperatures, UV radiation, dryness, and saline and water stress (Singh et al. 2010). In fact, this metabolic plasticity has made it possible to find them in most soils and to maintain a high level of diversity and abundance in different ecosystems, including agro-ecosystems (Araujo et al. 2018).

Nevertheless, the formulation and subsequent inoculation of these agents will depend on various aspects. For instance, the microbial state (live microorganism or metabolic extract; fresh or dry biomass), mode of application (aerial, root, seed), as well as the moment in which is applied. In this last case, a preventive method could be used prior to the presence of the pathogen, or curative, after the outbreak of the infection (Han et al. 2012; Palaniyandi et al. 2013).

Several cyanobacterial strains of Oscillatoria, Anabaena, Nostoc, Nodularia, and Calothrix, isolated from different soils are known as antifungal agents against plant pathogens such as Alternaria alternate, Botrytis cinerea, or Rhizopus stolonifer (Kim 2006). Exo-metabolites from the cyanobacteria Nodularia harveyana and Nostoc insulare show antibacterial and antifungal activities (Volk and Furkert 2006). Extracellular diterpenoids of Nostoc commune also exhibit antibacterial properties (Jaki et al. 2000). Moreover, microalgae possess molecules that can act as biopesticides, thus protecting the plant against pathogens, mainly fungi or bacteria. Specifically, the production of antibiotics and siderophores from Chlorella and Scenedesmus and other marine or freshwater microalgae has been previously described (Mendiola et al. 2007; Lee et al. 2020; Alsenani et al. 2020). However, although the use of ultrasound for the control of cyanobacterial and microalgal blooms has been widely studied, the application of sonicated extracts for phytostimulation and plant disease control is a novel topic for which only very 
recent references are available. In this sense, recent studies have shown that the inoculation of some cyanobacterial extracts from Calothrix sp., Nostoc spp. or Trichormus sp. significantly brought about beneficial changes in cucumber seedlings as well as the control of some plant pathogens (Toribio et al., 2020, 2021).

Based on the above, the main aim of this study was to evaluate the potential bioprotective and biostimulant effect of a collection of sonicated extracts from 5 microalgae and 3 cyanobacteria against the pathogenic bacterium $C$. michiganensis subsp. michiganensis (tomato canker) in tomato seedlings. Both effects were evaluated by using in vitro and in vivo methods and considering different forms of plant treatment (root irrigation and foliar spray). This study will lay the foundations for future research on the use of cyanobacteria and microalgae as important agro-biotechnological tools, not only for their recognized biofertilizing capacity but also for the management of devastating phytopathogenic bacteria.

\section{Materials and methods}

\section{Microorganisms}

\section{Phytopathogenic agent}

A lyophilized sample of the strain Clavibacter michiganensis subsp. michiganensis CECT 790 was supplied by the Spanish Type Culture Collection (CECT, Valencia, Spain) and then reconstituted in Nutrient Agar plates (NA, CM0003, Oxoid Ltd. UK) and kept in slant at $4{ }^{\circ} \mathrm{C}$.

\section{Collection of cyanobacteria and microalgae and getting extracts}

Five microalgae, Chlorella sp.-1, Chlorella sp.-361, Chlorella sp.-519, Chlorella sp.-568, and Scenedesmus sp.-677 and three cyanobacteria, Nostoc sp.-150, Nostoc sp.-251, and Leptolyngbya sp.-1267 were provided as lyophilized biomass from the Mosonmagyaróvár Algal culture collection (MACC, Mosonmagyaróvár, Hungary) and the Spanish Bank of Algae (SBA, Gran Canaria, Spain). For extract preparation, a stock solution was prepared by suspending $100 \mathrm{mg}$ of lyophilized biomass (LB) from each cyanobacterium and microalgae strain in $1 \mathrm{~mL}$ of sterile distilled water. The solution was subjected to a sonication process at $40 \%$ amplitude for $3 \mathrm{~min}$ (Branson Digital Sonifier SFX 150). The extracts were centrifuged at $4,000 \times g$ for 5 min and the supernatants were kept in a cold chamber at $4{ }^{\circ} \mathrm{C}$ until use. Following the recommendations of some authors (Navarro-López et al. 2020; Carneiro et al. 2021; Masojídek et al. 2021), the stock extracts were subsequently diluted in sterile distilled water at $25,10,2,0.5$, and $0.1 \mathrm{mg} \mathrm{mL} \mathrm{m}^{-1}$ depending on the bioassays to be performed.

\section{In vitro bioassays}

\section{Antibacterial activity against Clavibacter michiganensis subsp. michiganensis}

Once the cyanobacteria and microalgae biomasses were sonicated and diluted to $10 \mathrm{mg} \mathrm{mL}^{-1}$, their biological activities were tested against $C$. michiganensis subsp. michiganensis by a well diffusion assay following the protocol described by Suárez-Estrella et al. (2019). First, 2\% water agar (WA) plates were prepared. Over the solidified agar, four $8 \mathrm{~mm}$ diameter steel cylinders were placed equidistant from the edge of the Petri dish. A second layer of NA was added on the WA plates. Once NA had solidified, the cylinders were removed. A $48 \mathrm{~h}$ old $C$. michiganensis subsp. michiganensis culture prepared in $5 \mathrm{~mL}$ of Nutrient Broth (NB, CM0001 Oxoid Ltd. UK) and incubated at $30 \pm 1{ }^{\circ} \mathrm{C}$ under dark conditions was spread over the surface of the double layer of culture medium with a sterile swab previously soaked in the bacterial culture. The wells were filled with $70 \mu \mathrm{L}$ of the different extracts. Four replicates were considered for each extract-C. michiganensis subsp. michiganensis combination, each corresponding to one well of the same Petri dish. A Petri dish inoculated only with the phytopathogenic bacterium and confronted with distilled water inside the wells was considered a negative control of the assay. The whole experiment was repeated twice. Finally, inhibition of in vitro growth of $C$. michiganensis subsp. michiganensis was measured after incubating the plates at $30 \pm 1{ }^{\circ} \mathrm{C}$ under dark conditions for $48 \mathrm{~h}$. The inhibition index (I) was expressed as the percentage of $C$. michiganensis subsp. michiganensis growth inhibition in the presence of the antagonistic strain using the following formula:

$I=100-[G-(D-8) / 90] \times 100$

where $I$, inhibition index (\%); $G$, growth of the phytopathogenic agent in absence of the antagonistic extract (in this case it would be $90 \mathrm{~mm}$, since the bioassays were carried out in $90 \mathrm{~mm}$ Petri dishes); $D$, diameter of growth inhibition around the wells in presence of antagonistic extracts (mm).

\section{Determination of salicylic acid and cytokinins in sonicated extracts}

Sonicated, centrifuged, and filtered extracts of cyanobacteria and microalgae for quantification of salicylic acid (SA) and cytokinins (CKs) were used at the concentration of $100 \mathrm{mg} \mathrm{LB} \mathrm{mL}^{-1}$ and $25 \mathrm{mg} \mathrm{LB} \mathrm{mL}^{-1}$, respectively. The quantification of both phytohormones was carried out by 
immunodiagnostic tests according to the supplier's instructions (Plant Cytokinin CYT ELISA Kit, MyBiosource ref. MBS269996; Plant Salicylic acid SA ELISA Kit, MyBiosource ref. MBS9314138). The absorbance of the samples was measured at $450 \mathrm{~nm}$, in a Thermo Scientific Multiskan FC spectrophotometer and three replicates were taken into account for the analysis of the results. SA content was expressed in $\mu \mathrm{g} \mathrm{mL} L^{-1}$, while CKs was expressed in $\mathrm{ng} \mathrm{mL} \mathrm{m}^{-1}$.

\section{Effect of sonicated extracts on germination of watercress seeds}

The bioassay to evaluate the stimulating effect of extracts on watercress seed germination was previously described by Zucconi et al. (1981). Promotion effect was tested on four replicates of 25 seeds for each cyanobacterial and microalgae extract prepared at 2 and $0.5 \mathrm{mg} \mathrm{LB} \mathrm{mL}^{-1}$. To calculate germination index (GI), percentage of seed germination and elongation of the radicle $(\mathrm{mm})$ were taken into account, based on the following formula:

$G I=\left(G_{e} \% \times R E_{e}\right) /\left(G_{d w} \% \times R E_{d w}\right) \times 100$

where $G I$, germination index (\%); $G_{e} \%$, percentage of germinated seeds in presence of extract; $G_{d w} \%$, percentage of germinated seeds in presence of distilled water; $R E_{e}$, mean of radicle elongation $(\mathrm{mm})$ in presence of extract; $R E_{d w}$, mean of radicle elongation $(\mathrm{mm})$ in presence of distilled water.

\section{In planta bioassays: treatment of tomato seedlings with sonicated extracts of cyanobacteria and microalgae}

\section{Protective effect of the cyanobacteria and microalgae extracts by foliar and vascular application towards $C$. michiganensis subsp. michiganensis on tomato seedlings}

The most effective cyanobacterial and microalgae extracts selected from preliminary experiments (in vitro) were in vivo assayed by foliar and root application to evaluate the preventive effect towards $C$. michiganensis subsp. michiganensis. For this purpose, a sterile substrate mixture was initially prepared (peat:vermiculite at 3:1 ratio). The substrate was spread out on seedling trays with 77 alveoli and then regularly irrigated. A tomato seed (Solanum lycopersicum var. San Pedro) was sown in each alveolus and germinated for 3 weeks (up to two true leaves) at $25{ }^{\circ} \mathrm{C}, 60 \%$ humidity, and a 12-h photoperiod in a climate control chamber (ERIS 615 HR, Equitec). Then, the extracts were prepared as described in the "Material and methods" section (the "Collection of cyanobacteria and microalgae and getting extracts" section), but in this case, only the $0.1 \mathrm{mg} \mathrm{mL}^{-1}$ dilution was applied.

The root treatment was carried out by watering the substrate at the rhizosphere level of each seedling with $25 \mathrm{~mL}$ of the sonicated, centrifuged, and filtered extract. In parallel but in different plant sets, the foliar treatment was carried out by spraying $1 \mathrm{~mL}$ of the extracts on the leaf surface of the seedling. Both treatments were carried out in random blocks. Three blocks of 30 seedlings each were evaluated per treatment. Blocks of 30 untreated plants (negative controls) were also evaluated in parallel.

\section{Protocol for inoculation of tomato seedlings with C. michiganensis subsp. michiganensis and monitoring of infection status}

A C. michiganensis subsp. michiganensis culture was incubated in $50 \mathrm{~mL} \mathrm{NB}$ for $48 \mathrm{~h}$, at $28{ }^{\circ} \mathrm{C}$ and shaking at $120 \mathrm{rpm}$. After incubation, $20 \mathrm{~mL}$ of the culture was centrifuged for $20 \mathrm{~min}$ at $2800 \times \mathrm{g}$, the supernatant was removed, and the precipitate was washed twice with $5 \mathrm{~mL}$ of $0.9 \%$ $\mathrm{NaCl}$. Finally, the pellet was washed with $5 \mathrm{~mL}$ of sterile distilled water and the cell density was adjusted to approximately $10^{5}$ cfu $\mathrm{mL}^{-1}$ by counting in a Neubauer chamber.

One week after foliar and root application with the sonicated extracts of cyanobacteria and microalgae, tomato seedlings were artificially infected with the $C$. michiganensis subsp. michiganensis inoculum. The inoculation method was adapted from Fatmi and Schaad (2002). In this case, twenty micro-wounds were made in the stems of tomato seedlings at the level of the second or third true leaf using a sterile needle. Artificial infection of the plants was carried out with the help of a sterile swab soaked in about $500 \mu \mathrm{L}$ of the previously prepared suspension of the phytopathogenic bacteria $\left(10^{5} \mathrm{cfu} \mathrm{mL}^{-1}\right.$ of $\mathrm{Cmm}$ ). A block of 30 plants not previously treated with any extract (positive controls) was also infected with $\mathrm{Cmm}$. Another block of uninfected and untreated thirty plants was considered the negative control of the bioassay.

The typical symptoms of $C$. michiganensis subsp. michiganensis were periodically monitored over 3 weeks, taking into account the visual aspect of the infected plants. At 20-day post-infection, the level of affection of the plants was evaluated by applying a scale from 0 to 4 , depending on the presence or absence of symptoms, being $0=$ healthy plant, $1=$ local lesions in the stem, $2=$ mild wilting or decay, $3=$ wilting and marginal necrosis on leaves, and $4=$ death plant. After monitoring symptoms, stem portions from infected and negative control plants were surface-disinfected with ethanol for $5 \mathrm{~s}$ and rapidly flamed, macerated, and plated on Yeast Dextrose Carbonate Agar (YDC: yeast extract, $10 \mathrm{~g}$; glucose, $20 \mathrm{~g}$; $\mathrm{CaCO}_{3}, 20 \mathrm{~g}$; Agar, $15 \mathrm{~g}$; distilled water, $1000 \mathrm{~mL}$ ) to confirm the presence of 
typical C. michiganensis subsp. michiganensis colonies. This protocol was used to establish the infectivity index, which was expressed as the percentage of plants from which the pathogen bacterium was detected on YDC agar medium.

\section{Evaluation of foliar and root application of cyanobacterial and microalgae extracts on tomato seedlings}

Blocks of plants not infected with C. michiganensis subsp. michiganensis but previously treated by foliar and vascular route with extracts of cyanobacteria and microalgae were evaluated. The objective in this case was to establish the capacity of these extracts to stimulate the development of tomato seedlings according to the different treatments. The phytostimulant effect was evaluated as previously described by Santoro et al. (2011). Thereby, the following parameters were measured to evaluate the plant vigor: stem and root length $(\mathrm{cm})$, stem diameter $(\mathrm{mm})$, fresh and dry weight $(\mathrm{g})$, and root/stem ratio $(R / S$ ratio $)$.

\section{Statistical analyses}

The data obtained were subjected to statistical analysis using the Statgraphics Centurion XVII program. The normal distribution of the data was confirmed by means of Royston's test and the determination of the kurtosis index (Royston 1983; Svantesson and Wallace 2003). A dendrogram was used to examine the merging of hierarchical clusters (Schonlau 2004; Johnson and Wichern 2007). Thus, a linkage between groups was used as a grouping method for the variables analyzed in vitro. The interval measured in this case was the Euclidean distance squared. In addition, in vitro variables were also correlated by calculating the Spearman correlation coefficient at $P<0.05$. The selection of the best phytostimulant and biopesticide strains was finally carried out by applying a multivariate analysis of variance (ANOVA) and a Fisher multiple comparison test (least significant difference test) at $P<0.05$.

\section{Results}

\section{In vitro bioassays}

\section{Antibacterial activity against Clavibacter michiganensis subsp. michiganensis}

The effects of the sonicated microbial extracts from cyanobacteria and microalgae were analyzed in vitro against the growth of C. michiganensis subsp. michiganensis ( $\mathrm{Cmm}$ ), the agent responsible for bacterial canker in tomato plants. A set of tests was performed using the previously described well diffusion assay (see the "Antibacterial activity against Clavibacter michiganensis subsp. michiganensis" section).

Results suggested the capability of some of the tested strains to inhibit significantly the growth of $C$. michiganensis subsp. michiganensis in vitro (Fig. 1a), especially Leptolyngbya-1267, and Scenedesmus-677, which exhibited a remarkable inhibitory effect against $C$. michiganensis subsp. michiganensis (17 and 20\%, respectively) (Fig. 1a). On the contrary, a more discrete antagonistic effect was detected for the rest of the strains, being almost insignificant in the case of Nostoc-150 (less than 3\%). For this reason, Leptolyngbya-1267 and Scenedesmus-677 were considered powerful candidates to be further evaluated in planta
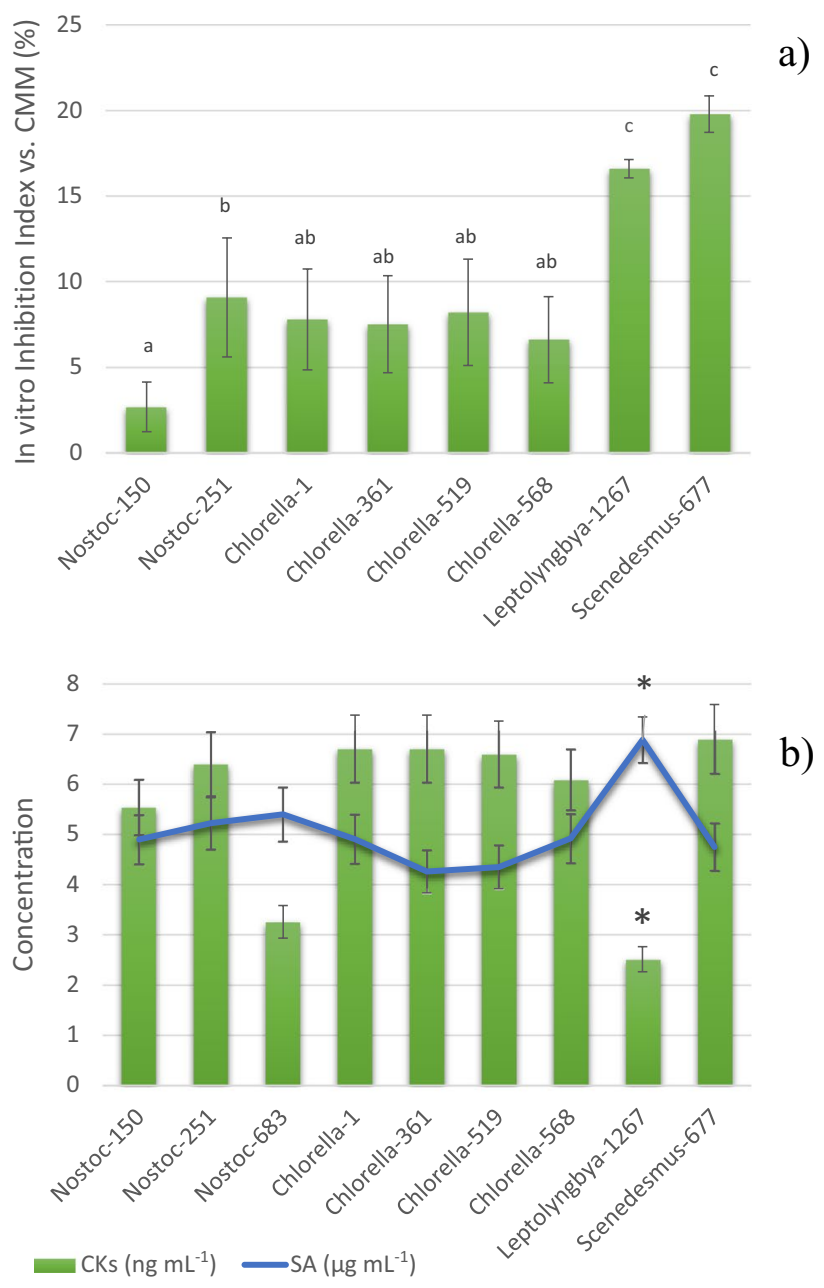

Fig. 1 a In vitro antagonistic effect of sonicated extracts of microalgae and cyanobacteria against the growth of Clavibacter michiganensis subsp. michiganensis (CMM). Bars indicate standard error. The letters above the bars indicate different homogeneous groups with statistically significant differences (Fisher's LSD test, $P<0.05$ ). b Cytokinins (CKs, $\left.\mathrm{ng} \mathrm{mL} \mathrm{m}^{-1}\right)$ and salicylic acid $\left(\mathrm{SA}, \mu \mathrm{g} \mathrm{mL} \mathrm{L}^{-1}\right)$ concentration in sonicated extracts of microalgae and cyanobacteria. Bars indicate standard error. Asterisks show different homogeneous groups with statistically significant differences (Fisher's LSD test, $P<0.05$ ) 
bioassays against $C$. michiganensis subsp. michiganensis infection.

\section{Determination of salicylic acid and cytokinins in sonicated extracts}

All the cyanobacterial and microalgal extracts were tested for the production of cytokinins (CKs) and salicylic acid (SA). In the case of CKs, the values ranged between 5 and $7 \mathrm{ng} \mathrm{mL}{ }^{-1}$ in most of the extracts analyzed. However, the lowest significant value of CKs was shown in the extract from Leptolyngbya-1267 strain $\left(3 \mathrm{ng} \mathrm{mL}^{-1}\right.$ ) (Fig. 1b). The data related to the production of salicylic acid (SA) ranged between 5 and $7 \mu \mathrm{gL}^{-1}$. In this case, the values were significantly higher in the extract from Leptolyngbya-1267 (Fig. 1b). It should be noted that the SA/CK ratio in all the extracts analyzed was lower than 1000 , except for the strain Leptolyngbya-1267 whose SA/CK ratio was close to 3000 (SA concentration is expressed as $\mu \mathrm{g} \mathrm{mL} L^{-1}$ while for CK it is in $\mathrm{ngL}^{-1}$ ).

\section{Effect of sonicated extracts on germination of watercress seeds}

The sonicated extracts from the collection of cyanobacteria and microalgae were evaluated to determine their phytotoxic or phytostimulant effect by in vitro application on watercress seeds (Fig. 2).

According to Zucconi et al. (1981), a GI value above $70-80 \%$ indicates the absence of phytotoxicity, while a value close to or greater than $100 \%$ is indicative of a plant growth

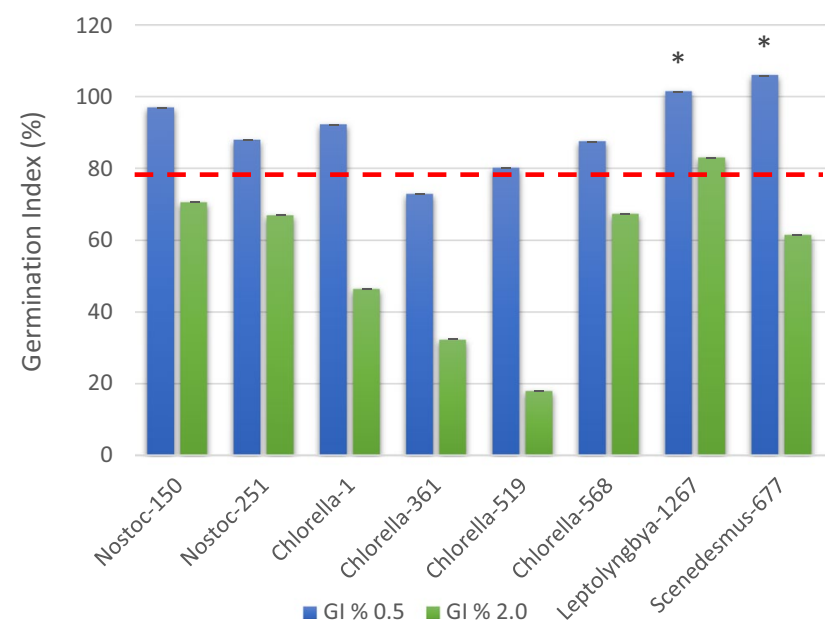

Fig. 2 Effect of the application of sonicated extracts of microalgae and cyanobacteria on germination index (GI) in watercress seeds. GI $\% 0.5$, extracts applied at a rate of $0.5 \mathrm{mg} \mathrm{mL}^{-1}$; GI \% 2.0, extracts applied at a rate of $2.0 \mathrm{mg} \mathrm{mL}-1$. Bars indicate standard error. Asterisks show the homogeneous groups with the highest statistically significant GI value (Fisher's LSD test, $P<0.05$ ) promoting effect. As shown on Fig. 2, almost all extracts applied at $0.5 \mathrm{mg} \mathrm{mL}^{-1}$ were positioned at GI values between 80 and $110 \%$, showing an average GI value higher than $90 \%$. Still, it should be noted that the highest phytostimulant potential was shown by the extracts of Leptolyngbya-1267 and Scenedesmus-677 at a concentration of $0.5 \mathrm{mg} \mathrm{mL}^{-1}$. In contrast, the results derived from the extracts applied at $2.0 \mathrm{mg} \mathrm{mL}^{-1}$ showed an apparently negative effect. In this case, GI values ranged between 18 and $70 \%$, corresponding to potentially phytotoxic extracts. Only the GI value from Leptolyngbya-1267 extract stayed out the range of phytotoxicity at a concentration of $2.0 \mathrm{mg} \mathrm{mL}^{-1}$.

\section{Clustering and correlation analyses}

A clustering analysis was performed based on all the parameters measured in vitro, which were inhibition index (\%), phytohormone production (CKs and SA), and germination index $(\%)$ in watercress seeds at different extract concentrations. This analysis allowed to observe the grouping of the strains according to the biopesticidal and phytostimulant profile shown in each case. The $\mathrm{Y}$ axis in Fig. 3a represents distance between groups. From this analysis, two large classification groups were established. On the one hand, a group formed by all the Chlorella strains could be observed, which corresponded to a medium-low level of inhibition against C. michiganensis subsp. michiganensis (Fig. 1a), a SA/CK ratio lower than 1000 (Fig. 1b), and a notable degree of phytotoxicity on the germination when extracts were used at high concentrations (Fig. 2). This criterion also served to differentiate, in turn, two subgroups: one of them formed by those strains that were phytotoxic at the two concentrations tested (Chlorella-361 and Chlorella-519), and another one formed by those others that were phytotoxic only when applied at high concentrations (Chlorella-1 and Chlorella-568) (Fig. 3a). Nostoc-150, Nostoc-251, and Scenedesmus-677 clustered in another separated group, characterized by a high level of antagonism against $C$. michiganensis subsp. michiganensis (Fig. 1a), a SA/CK ratio less than 1000 (Fig. 1b) and unremarkable germination indices, except in the case of Scenedesmus-677, when it was applied at a low extract concentration (Fig. 2). This last strain was selected for subsequent tests due to its special relevance as an antagonism agent against $C$. michiganensis subsp. michiganensis as well as for its ability to promote the seed germination in vitro. Finally, Leptolyngbya-1267 was grouped independently of the others (Fig. 3a). Considering the distance that separates this strain from the others in the dendrogram, it can be deduced that its biopesticidal and phytostimulant capacity makes it a strain with special potential to be used as a biological control agent. This strain shows a remarkable antagonistic power against $C$. michiganensis subsp. michiganensis (Fig. 1a) and favors the germination 

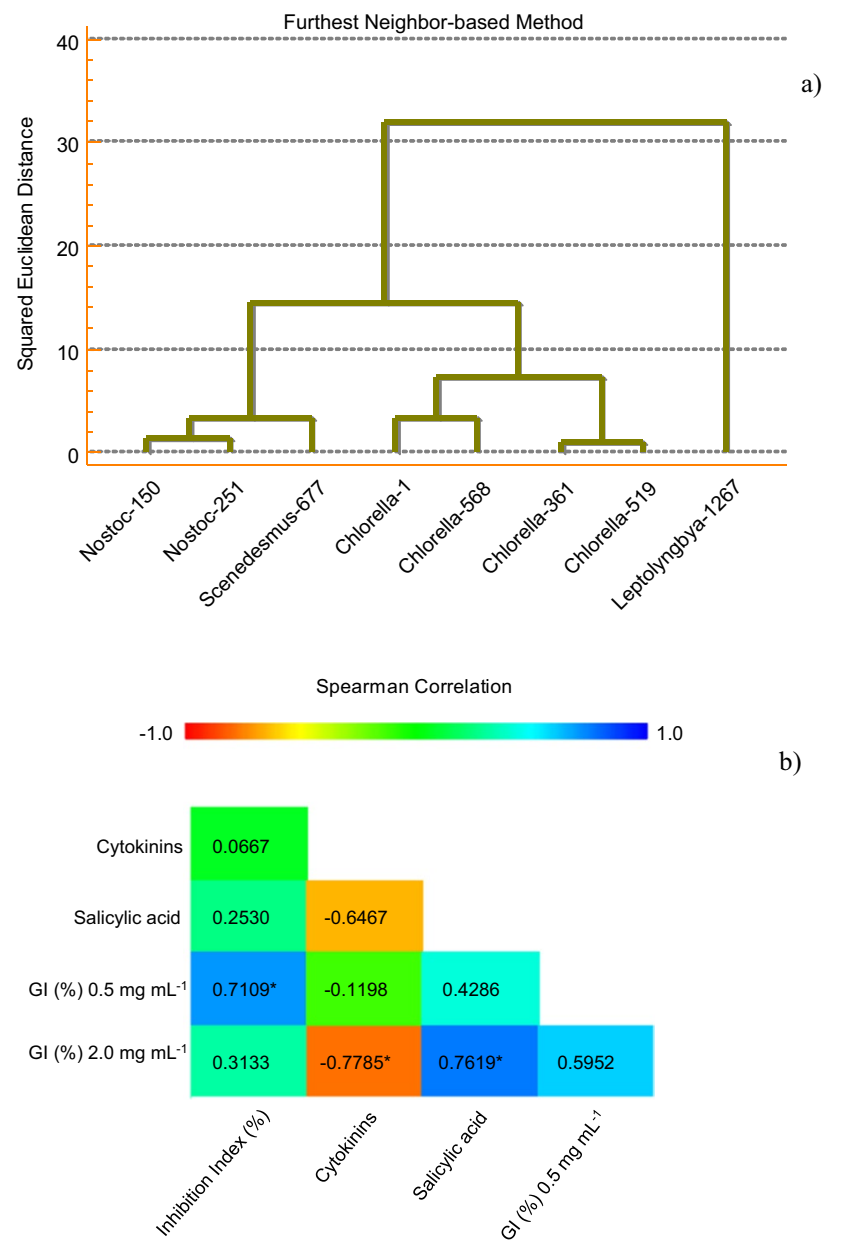

b)

Fig. 3 a Hierarchical cluster analysis (furthest neighbor-based clustering Euclidean distance squared). The sonicated extracts are grouped into several clusters so that the members within any cluster are the most similar according to the results obtained in vitro (inhibition index, GI, CKs, SA). b Spearman correlation analyses $(P<0.05)$ from results obtained in vitro (inhibition index, GI, CKs, SA). Asterisks indicate statistically significant correlations at $95 \%$ confidence level

of watercress seeds, without showing phytotoxicity problems (Fig. 2). Furthermore, the SA/CK ratio is around 3000, showing a significant level of SA production compared to the other strains tested (Fig. 1b). It should be noted that this substance is considered an important regulator of plant growth with great impact on the increase of the root system (Larqué-Saavedra et al. 2010), as well as on the activation of the salicylic acid-dependent resistance pathway in plants (Chaturvedi and Shan 2007).

Figure $3 \mathrm{~b}$ shows a Spearman correlation analysis for all the parameters previously analyzed in vitro. It was possible to establish a very strong and significant negative relationship between the GI at $2 \mathrm{mg} \mathrm{mL}^{-1}$ and the production of CKs $(r=-0.778)$. However, the correlation between GI at $2 \mathrm{mg} \mathrm{mL}^{-1}$ and SA production was significant and strongly positive $(r=0.762)$. Therefore, the importance of the SA/ CK ratio in the analyzed extracts must be highlighted, since higher values of this parameter could lead to less toxicity of the extracts in the germination phase. On the other hand, a very interesting (but not significant) positive correlation was detected between the GI at $0.5 \mathrm{mg} \mathrm{mL}^{-1}$ and the value of the inhibition index against $\mathrm{Cmm}$ (Fig. 3b). This fact could be indirectly related to the high production of SA by Leptolyngbya-1267. However, this explanation is not sufficient to justify the notorious antagonistic effect against $C$. michiganensis subsp. michiganensis in the case of Scenedesmus-677. Scenedesmus spp. appear to be a rich source of new antimicrobial substances. In fact, Marrez et al. (2019) reported the antimicrobial activity of several species of Scenedesmus against different pathogenic bacteria. Therefore, other bioactive metabolites are suspected to be responsible for the antagonistic activity in the case of the latter strain.

\section{In planta bioassays: treatment of tomato seedlings with sonicated extracts of cyanobacteria and microalgae}

\section{Protective effect of the cyanobacteria and microalgae extracts by foliar and root application towards $C$. michiganensis subsp. michiganensis on tomato seedlings}

From the results described above, strains Leptolyngbya-1267 and Scenedesmus-677 were selected as possible biological control agents against $C$. michiganensis subsp. michiganensis. In order to evaluate its effectiveness in planta, a bioassay was developed based on two different preventive application protocols: foliar and root. One week after the treatment with the sonicated extracts, the tomato seedlings were artificially infected with $C$. michiganensis subsp. michiganensis. After a reasonable time to ensure the appearance of disease symptoms, approximately 3-4 weeks, the plant health condition was measured taking into account a score from 0 to 4 (see the "Protocol for inoculation of tomato seedlings with C. michiganensis subsp. michiganensis and monitoring of infection status" section). Based on the collected data, the health condition in plants root pre-treated with Scenedesmus-677 and then infected with $C$. michiganensis subsp. michiganensis was less than 2, according to the scale mentioned above (Fig. 4a). This involved the appearance of very mild symptoms. The rest of preventive pretreatments did not cushion significantly the symptoms provoked by $C$. michiganensis subsp. michiganensis under the application conditions used. Only the treatment with Leptolyngbya-1267 via foliar achieved a weak mitigation of the most severe symptoms, showing a moderate yellowing of the plant. The seedlings destined for Positive Controls of $C$. michiganensis subsp. michiganensis, had a health condition around 3 , showing wilting and leaf marginal necrosis, as well 


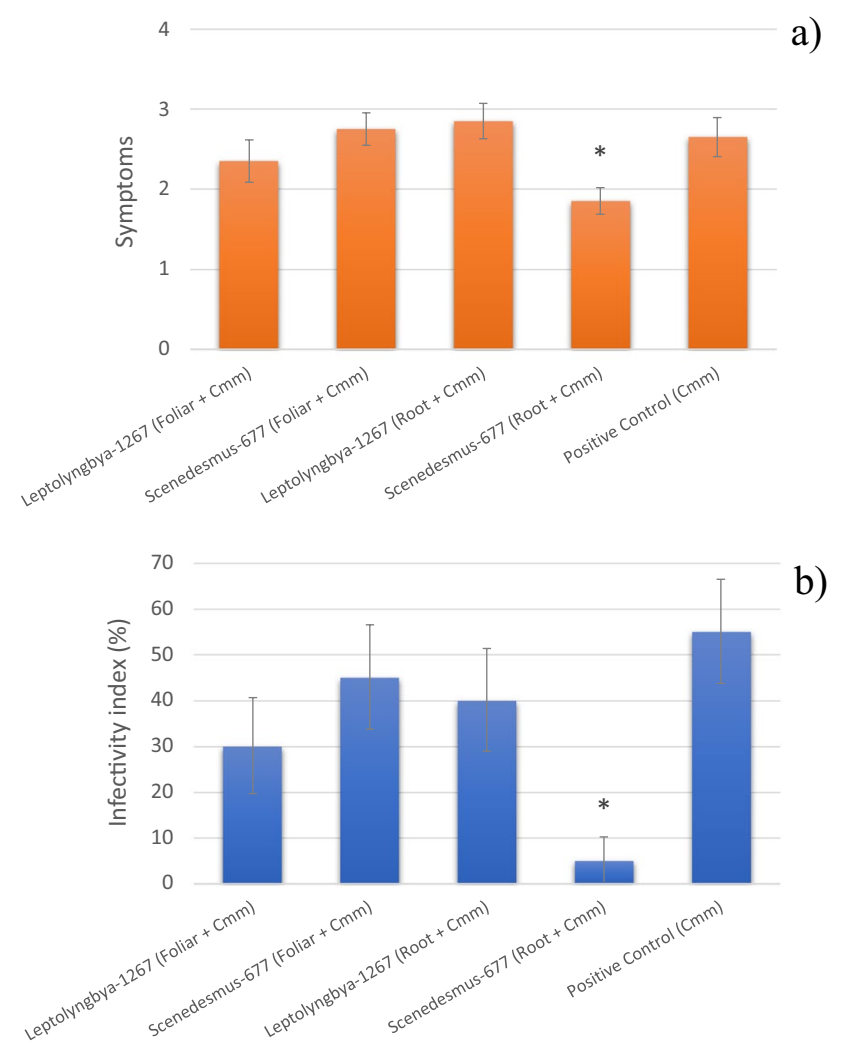

Fig. 4 Protective effect of Leptolyngbya-1267 and Scenedesmus-677 by foliar and root application towards Clavibacter michiganensis subsp. michiganensis on tomato seedlings: a symptoms and b infectivity index (\%). Bars indicate standard error. Asterisks show different homogeneous groups with statistically significant differences (Fisher's LSD test, $P<0.05$ )

as stem damage. Negative controls (without pre-treatment nor $\mathrm{Cmm}$ ) did not show typical symptoms of bacterial canker (data not shown).

On the other hand, Fig. 4b shows the percentage of plants from which $C$. michiganensis subsp. michiganensis was isolated. In this case, the percentage of infected plants was evaluated by means of a parameter named infectivity index (see the "Protocol for inoculation of tomato seedlings with C. michiganensis subsp. michiganensis and monitoring of infection status" section). Both strains chosen for the in vivo assay were able to reduce the infectivity index in the plant-blocks previously treated and infected with $C$. michiganensis subsp. michiganensis. Nevertheless, only when Leptolyngbya-1267 and Scenedesmus-677 was applied by root and foliar way respectively, a significant decrease of infectivity index was detected (Fig. 4b). The most effective treatment corresponded to Scenedesmus-677 via root, showing an infectivity index around 10\% (approximately 90\% lower than in the $\mathrm{Cmm}$-infected control plant block). The next most important extract due to its biopesticidal effect was that of Leptolyngbya-1267 applied by foliar application, showing a decrease in infectivity of around 50\%, compared to what was observed in the positive controls (Fig. 4b).

\section{Evaluation of foliar and root application of cyanobacterial and microalgae extracts on tomato seedlings}

In addition to the protective effect against the disease caused by $C$. michiganensis subsp. michiganensis, a bioassay was developed to examine the in vivo biostimulant ability of extracts from the two previously selected microorganisms, Leptolyngbya-1267 and Scenedesmus-677. The foliar and root pretreatments were applied according to the protocol described in the "Evaluation of foliar and root application of cyanobacterial and microalgae extracts on tomato seedlings" section. After 3 weeks from the application of both treatments, different parameters associated with the plant growth were evaluated.

In general terms, both treatments improved the vegetative (aerial) growth of the plants as well as the development of the roots. Specifically, data related to plant size and aerial growth were noticeable when foliar treatment was applied from both microbial extracts. The data concerning length and diameter of the stem, and fresh and dry weight were significantly higher than those detected in the control plants when the foliar treatment was carried out with both extracts (Fig. 5a, d, e, f). In this case, Leptolyngbya-1267 extracts applied via foliar were better over the root application. On the other hand, regarding the development of the roots, no significant differences were globally detected between both treatments (foliar and root application). However, a higher root size was suspected in the case of root application, especially with Leptolyngbya-1267 extracts (Fig. 5b, c).

When looking at the data collected in Fig. 5 as a whole, the relevant role of Leptolyngbya-1267 and Scenedesmus-677 extracts in promoting plant growth becomes evident. In this sense, the foliar application of the extracts was positioned as the most effective biostimulant treatment to improve the development of the aerial part of the plant, while the root application was more efficient in improving the radicular development. Therefore, the plant growth-promoting effect seems to be closely related to the mode of application of the extracts. Nonetheless, there is no doubt that these are two promising strains with a marked biostimulant effect on tomato seedlings.

\section{Discussion}

\section{In vitro bioassays}

Antimicrobial compounds from cyanobacteria and microalgae are involved in the biological control of diseases that affect vegetable crops. This is the case of 
Fig. 5 Plant growth promoting effect by foliar and root application of Leptolyngbya-1267 and Scenedesmus-677 extracts. a Stem length $(\mathrm{cm})$; b root length (cm); c $R / S$ ratio; d stem diameter (mm); e fresh weight ( $\mathrm{g}$ ); f dry weight $(\mathrm{g})$. Bars indicate standard error. The letters above the bars indicate different homogeneous groups with statistically significant differences (Fisher's LSD test, $P<0.05$ )

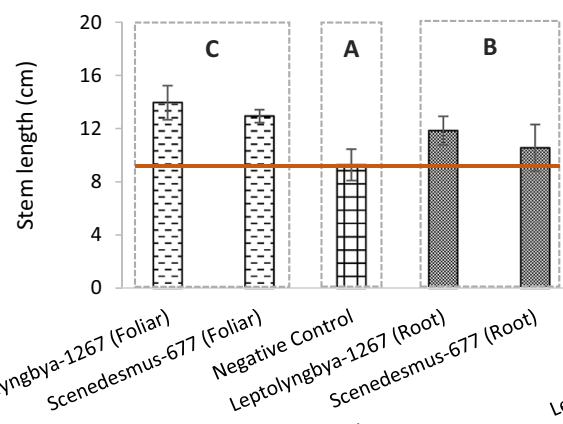

a)

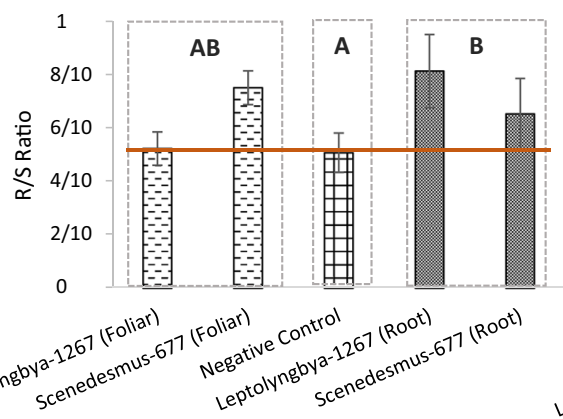

c)
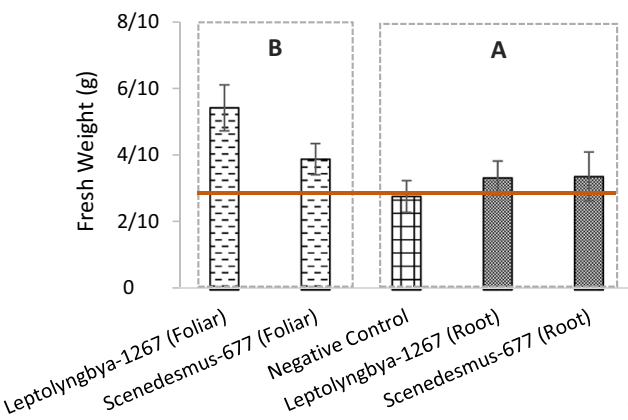

e)

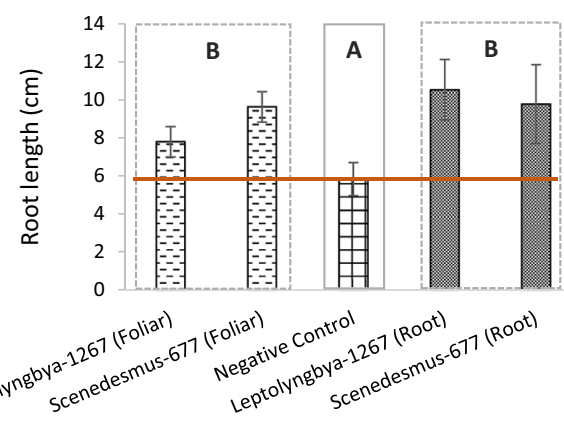

b)

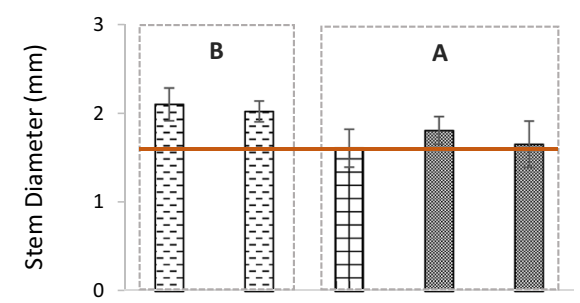

d)

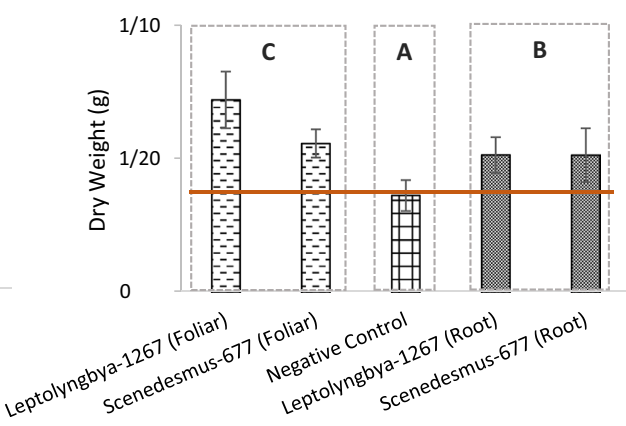

f) chlorine-containing antibiotics detected in Scytonema spp., majusculamide in Anabaena laxa, or benzoic acid in Calothrix spp. (Natarajan et al. 2012; Singh 2014). Moreover, in many cases, cyanobacteria enhance the defensive activities of plants by promoting the production of enzymes and other bioactive substances (Prasanna et al. 2008). In fact, some strains of Anabaena spp. and Calothrix spp. are associated with the production of chitosanase and endoglucanase like-enzymes, showing similarity with other plant growth promoting microorganisms (El-Mougy and Abdel-Kader 2013; Gupta et al. 2013; Natarajan et al. 2013). On the other hand, green microalgae such as Coccomyxa onubensis (Navarro et al. 2017), Tetraselmis suecica (Austin et al. 1992), and Chlorella minutissima (Katharios et al. 2005) are also reported to have antimicrobial properties. Thus, some extracts from microalgae also contain bioactive compounds such as polyphenols, tocopherols, carbohydrates, proteins, oils, and pigments with antimicrobial properties, which can be helpful in pathogen control against soil borne diseases (Michalak and Chojnacka 2015).

However, there is no relevant background that highlights the role of cyanobacteria and microalgae specifically against bacterial canker caused by $C$. michiganensis subsp. michiganensis in tomato. Therefore, the results obtained in this work were surprising. These results suggest that some compounds derived from Leptolyngbya-1267 and Scenedesmus-677 could be considered a promising and sustainable alternative for the treatment of seeds, seedlings or soils against $C$. michiganensis subsp. michiganensis.

On the other hand, phytohormones play an important role in germination and plant growth. Many strains of microalgae and cyanobacteria are associated with the production of phytohormone-like substances (Gupta and Lata 1964; 
Stirk et al. 2002). Some of them are located intracellularly, while others are excreted into the surrounding environment (Mazur et al. 2001; Sergeeva et al. 2002; Lu and Xu 2015; Romanenko et al. 2015). Many reports have highlighted the use of phytohormones from microalgae and cyanobacteria for the in vitro plant regeneration, as well as for their use as plant growth-promoting substances in numerous crops (Hussain and Hasnain 2011; Jäger et al. 2010; Gayathri et al. 2015). Some of these studies have demonstrated the positive correlation between phytohormones produced by cyanobacteria and microalgae (cytokinin and auxin) and different plant growth parameters such as germination index, shoot length, root length, or seedling weight. Even more, an increase in the level of phytohormones around the rhizosphere has been attributed to the plant-cyanobacteria interaction or plant-microalgae interaction (Hussain and Hasnain 2011).

The phytohormones studied in this work have been selected not only for their important role in plant development but also for their direct or indirect involvement and relevance in plant resistance induction processes. On the one hand, CKs affect different physiological processes such as morphogenesis, apical dominance, senescence of leaves, development of chloroplasts, and seed inactivity (Hwang et al. 2012). Furthermore, CKs play a relevant role in the stimulation of the effector-triggered immune response and the signaling of salicylic acid (Igari et al. 2008). On the other side, nowadays, SA molecule is considered a plant growth regulator, favoring the rooting process, increasing root length and area, as well as the foliar area and the stem diameter in tomato plants (Larqué-Saavedra et al. 2010). This molecule is also involved in the physiological response to pathogens by the activation of the Systemic Acquired Resistance (SAR) in plants (Chaturvedi and Shan 2007).

The characterization of the tested extracts based on their ability to promote germination or to produce some type of bioactive substances (such as CKs and SA) could indirectly provide indications of the mode of action that a given microbial extract exerts on the control of a specific pathogen or on plant growth at different development phases. Some authors have highlighted that controlling or inhibiting the development of diseases caused by phytopathogens is related to a phenomenon of direct suppression, through the secretion of allelochemicals or secondary metabolites, or indirectly, through the induction of systemic resistance in the plant. In this last case, it would be possible the production of substances similar to phytohormones, inducers, or enzymes related to pathogenesis ( $\beta-1,3$ endoglucanase, chitinases, catalases, peroxidases, polyphenol oxidases, or phenylalanine ammonia lyase) (Gayathri et al. 2015; Attia et al. 2016).

Concerning the effect of sonicated extracts on germination of watercress seeds, results obtained in this work in general supported that the elongation of the radicle is lower when the concentration of the sonicated extracts of cyanobacteria and microalgae increases. This agrees with results published by other authors that confirmed the positive effect of the application of cyanobacteria at low extract concentrations (Dmytryk et al. 2014; Aghofack-Nguemezi et al. 2015; Godlewska et al. 2019), as well as the phytotoxic effect of excessively high concentrations of seaweed extracts on seed germination (Kumar and Sahoo 2011; Hernández-Herrera et al. 2013). Some authors have shown that the immersion of seeds in extracts of cyanobacteria and microalgae can improve their quality, by stimulating the germination and root elongation (Kumar and Sahoo 2011; Hernández-Herrera et al. 2013; Ibrahim 2016; Barone et al. 2018). In this sense, the results described here are promising in relation to the potential use of microalgae and cyanobacterial extracts in seed biopriming techniques.

\section{In planta bioassays}

Recent studies have shown the benefit of the inoculation of plants with phototrophic microorganisms, as promoters of plant growth (Ordög et al. 2004; Toribio et al. 2020). The results shown in this work confirm that certain strains of microalgae and cyanobacteria could be developed for use in the agro-biotechnology sector due to their enormous versatility to produce a wide range of metabolites involved in the protection and promotion of plant growth.

In view of the results observed in this work, the selection of strains carried out during the in vitro tests has been successful, since the biopesticidal effect detected in vitro against $C$. michiganensis subsp. michiganensis has been also validated in tomato seedlings infected with the pathogenic bacteria (Fig. 4). It should not be forgotten that the success of any biological control agent is a consequence of the interaction between the pathogen-plant and the rhizospheric microbial community (Weller et al. 2002; Moustaine et al. 2019). Therefore, it is not always possible to successfully reproduce the biopesticidal effect in vitro in other bioassays more in line with the reality of a pathological system.

Some authors argue that the use of this type of microorganisms as biofertilizers fundamentally affects the water regulation mechanisms of plants, contributing to the increase of chlorophyll in the leaves, delaying aging, improving seed germination, and benefiting the plant-soil system (Hegazi et al. 2010). Others directly relate the previously described biostimulant effect with the bioprotective capacity of the extracts in pretreated plants with cyanobacteria and microalgae. The application with this type of extracts could cause an increase in the absorption of nutrients, the accumulation of plant defenses against biotic stresses and the improvement of the performance in the treated plants (Prasanna et al. 2013). Some of the improvements above described could be due to the presence of some amino acids such as tryptophan and arginine 
in such extracts, which is associated with a significant increase in the plant growth and yield. It should be noted that both amino acids are the metabolic precursors of key phytohormones which are indispensable in the growth processes that lead to the formation of roots, stem, leaves, flowers, and fruits (Colla and Rouphael 2015). Moreover, the ability to produce polysaccharides attributed to microalgae could contribute to their enormous potential to be used as biostimulating agents, since such compounds have been shown to improve plant growth in Solanaceae crops (Elarroussi et al. 2016).

Despite the satisfactory results obtained in this work, it will be necessary to proceed with caution, given the lack of previous studies on the control of bacterial canker through the application of cyanobacteria and microalgae extracts. Therefore, the in vivo efficacy of the selected extracts against the disease caused by $C$. michiganensis subsp. michiganensis, as well as their effect on seed germination and seedling growth, should be analyzed in depth.

\section{Conclusions}

In view of the results obtained, it can be concluded that the application of cyanobacteria and microalgae to protect tomato crops from bacterial cankers provoked by Clavibacter michiganensis subsp. michiganensis could be of great agronomic interest. The biopesticidal effect demonstrated by the Leptolyngbya-1267 and Scenedesmus-677 strains could be closely related to their ability to promote plant growth as well as root development of tomato plants. According to the most relevant results, the root application of Scenedesmus-677 could be more aimed at controlling the disease, while the foliar and root application of Leptolyngbya-1267 seems more related to the strengthening of the plant and therefore, with an improvement in the plant defensive response. These results, although preliminary, will serve as a basis for further characterization of the sonicated extracts of Leptolyngbya-1267 and Scenedesmus-677, as well as for improving the extraction of bioactive substances from these samples and optimizing the protocols applied for biosafety and phytostimulation of tomato crop.

Acknowledgements The authors of this work appreciate the help provided by professors F.G. Acien (SABANA project coordinator), V. Ordög, and J.L. Gómez-Pinchetti, with respect to obtaining the collection of cyanobacteria used in this work.

Author contribution Ana J. Toribio: formal analyses, investigation, writing — original draft preparation, visualization. Macarena M. Jurado: investigation, resources, writing-review and editing. Francisca Suárez-Estrella: conceptualization, methodology, investigation, visualization, writing-review and editing. Juan A. López-González: investigation, resources. María R. Martínez-Gallardo: methodology, investigation. María J. López: methodology, supervision, resources, writing-review and editing.

Funding Open Access funding provided thanks to the CRUE-CSIC agreement with Springer Nature. This research was funded by SABANA Project (Grant No. 727874) from the EU Horizon 2020.

Data availability The datasets generated during and/or analyzed during the current study are available from the corresponding author on reasonable request.

\section{Declarations}

Competing interests The authors declare no competing interests.

Open Access This article is licensed under a Creative Commons Attribution 4.0 International License, which permits use, sharing, adaptation, distribution and reproduction in any medium or format, as long as you give appropriate credit to the original author(s) and the source, provide a link to the Creative Commons licence, and indicate if changes were made. The images or other third party material in this article are included in the article's Creative Commons licence, unless indicated otherwise in a credit line to the material. If material is not included in the article's Creative Commons licence and your intended use is not permitted by statutory regulation or exceeds the permitted use, you will need to obtain permission directly from the copyright holder. To view a copy of this licence, visit http://creativecommons.org/licenses/by/4.0/.

\section{References}

Aghofack-Nguemezi J, Schinzoumka PA, Tatchago V (2015) Effects of extracts or powder of Jatropha curcas and Spirulina platensis on the growth and development of tomato plant. J Appl Biosci 90:8413-8420

Aksoy H, Kaya Y, Ozturk M, Secgin Z, Onder H, Okumus A (2017) Pseudomonas putida induced response in phenolic profile of tomato seedlings (Solanum lycopersicum L.) infected by Clavibacter michiganensis subsp. michiganensis. Biol Control 105:6-12

Alsenani F, Tupally KR, Chua ET, Eltanahy E, Alsufyani H, Parekh HS, Schenk PM (2020) Evaluation of microalgae and cyanobacteria as potential sources of antimicrobial compounds. Saudi Pharm J 28:1834-1841

Araujo D, Hernández R, Vanegas J (2018) Cyanobacteria inoculation effect on interest commercial crops in semi-arid zones of La Guajira - Colombia. Rev Colomb Investig Agroindustriales 5(1):20-31

Attia MS, El-Monem MA, Sharaf A, Zayed AS (2016) Protective action of some bio-pesticides against early blight disease caused by Alternaria Solani in tomato plant. Int J Innov Res Sci Eng Technol 4:2348-7968

Austin B, Baudet E, Stobie M (1992) Inhibition of bacterial fish pathogens by Tetraselmis suesica. J Fish Dis 15:55-61

Barone V, Baglieri A, Stevanato P, Broccanello C, Bertoldo G, Bertaggia M, Cagnin M, Pizzeghello D, Moliterni VMC, Mandolino G, Fornasier F, Squartini A, Nardi S, Concheri G (2018) Root morphological and molecular responses induced by microalgae extracts in sugar beet (Beta vulgaris L.). J Appl Phycol 30:1061-1071

Carneiro M, Ranglová K, Lakatos GE, Câmara Manoel JA, Grivalský T, Kozhan DM et al (2021) Growth and bioactivity of two chlorophyte (Chlorella and Scenedesmus) strains co-cultured outdoors in two different thin-layer units using municipal wastewater as a nutrient source. Algal Res 56:102299 
Chaturvedi R, Shah J (2007) Salicylic acid in plant disease resistance. In: Hayat S, Ahmad A (eds) Salicylic Acid - A plant hormone. Springer, Dordrecht, pp 335-370

Colla G, Rouphael Y (2015) Biostimulants in Horticulture. Sci Hortic 196:39-48

De León L, Siverio F, López MM, Rodríguez A (2011) Clavibacter michiganensis subsp. michiganensis, a seedborne tomato pathogen: healthy seed are still the goal. Plant Dis 95:1328-1338

Deng P, Wang X, Baird SM, Lu SE (2015) Complete genoma of Pseudomonas chlororaphis strain UFB2, a soil bacterium with antibacterial activity against bacterial canker pathogen of tomato. Stand Genomic Sci 10:117

Dmytryk A, Rój E, Wilk R, Chojnacka K (2014) Innovative bioformulations for seed treatment. Preliminary assessment of functional properties in the initial plant growth phase. Przem Chem 93:959-963

EFSA Panel on Plant Health (2014) Scientific Opinion on the pest categorisation of Clavibacter michiganensis subsp. michiganensis (Smith) Davis et al. EFSA J. 12:3721

Elarroussi H, Elmernissia N, Benhimaa R, El Kadmiria IM, Bendaou N, Smouni A, Wahbya I (2016) Microalgae polysaccharides a promising plant growth biostimulant. J Algal Biomass Utln 7:55-63

El-Mougy NS, Abdel-Kader MM (2013) Effect of commercial cyanobacteria products on the growth and antagonistic ability of some bioagents under laboratory conditions. J Pathogens 2013: 838329

EPPO (2016) European and Mediterranean Plant Protection Organization Clavibacter michiganensis subsp michiganensis. EPPO Bull 46:202-225

Fatmi M, Schaad NW (2002) Survival of Clavibacter michiganensis ssp. michiganensis in infected tomato stems under natural field conditions in California, Ohio and Morocco. Plant Pathol 51:149-154

Gayathri M, Kumar PS, Prabha AML, Muralitharan G (2015) In vitro regeneration of Arachis hypogaea L. and Moringa oleifera Lam. using extracellular phytohormones from Aphanothece sp. MBDU 515. Algal Res 7:100-105

Gitaitis RD, Beaver RW, Voloudakis AE (1991) Detection of Clavibacter michiganensis subsp. michiganensis in symptomless tomato transplants. Plant Dis 75:834-838

Gleason ML, Braun EJ, Carlton WM, Peterson RH (1991) Survival and dissemination of Clavibacter michiganensis subsp. michiganensis in tomatoes. Phytopathology 81:1519-1523

Godlewska K, Michalak I, Pacyga P, Basladynska S, Chojnacka K (2019) Potential applications of cyanobacteria: Spirulina platensis filtrates and homogenates in agriculture. World J Microbiol Biotechnol 35:80

Gupta AB, Lata K (1964) Effect of algal growth hormones on the germination of paddy seeds. Hydrobiologia 24:430-434

Gupta V, Ratha SK, Sood A, Chaudhary V, Prasanna R (2013) New insight into the biodiversity and applications of cyanobacteria (blue-green algae) — prospects and challenges. Algal Res 2:79-97

Han SH, Kang BR, Lee JH, Kim HJ, Park JY, Kim JJ, Kim YC (2012) Isolation and characterization of oligotrophic bacteria possessing induced systemic disease resistance against plant pathogens. Plant Pathol J 28:68-74

Hegazi AZ, Mostafa SSM, Ahmed HMI (2010) Influence of different cyanobacterial application methods on growth and seed production of common bean under various levels of mineral nitrogen fertilization. Nat Sci 8:183-194

Heimpel GE, Mills NJ (2017) Biological control: ecology and applications.Cambridge University Press, Cambridge.

Hernández-Herrera RM, Santacruz-Ruvalcaba F, Ruíz-López MA, Norrie J, Hernández-Carmona G (2013) Effect of liquid seaweed extracts on growth of tomato seedlings (Solanum lycopersicum L.). J Appl Phycol 26(1):619-628
Herrero A, Flores E (2008) The cyanobacteria: molecular biology, genomics and evolution. Caister Academic Press, Norfolk

Hussain A, Hasnain S (2011) Phytostimulation and biofertilization in wheat by cyanobacteria. J Ind Microbiol Biotechnol 38:85-92

Hwang I, Sheen J, Müller B (2012) Cytokinin signaling networks. Annu Rev Plant Biol 63:353-380

Ibrahim WM (2016) Potential impact of marine algal extracts on the growth and metabolic activities of salinity stressed wheat seedlings. J Appl Sci 16:388-394

Igari K, Endo S, Hibara K, Aida M, Sakakibara H, Kawasaki T, Tasaka M (2008) Constitutive activation of a CC-NB-LRR protein alters morphogenesis through the cytokinin pathway in Arabidopsis. Plant J 55:14-27

Jäger K, Bartók T, Ördög V, Barnabás B (2010) Improvement of maize (Zea mays L.) anther culture responses by algae-derived natural substances. S Afr J Bot 76:511-516

Jaki B, Orjala J, Heilmann J, Linden A, Vogler B, Sticher O (2000) Novel extra-cellular diterpenoids with biological activity from the cyanobacterium Nostoc commune. J Nat Prod 63:339-343

Johnson RA, Wichern DW (2007) Applied Multivariate Analysis, 6th ed. Pearson Prentice Hall, NJ. 794 p.

Kasselaki AM, Goumas D, Tamm L, Fuchs J, Cooper J, Leifert C (2011) Effect of alternative strategies for the disinfection of tomato seed infected with bacterial canker (Clavibacter michiganensis subsp. michiganensis). NJAS - Wageningen J Life Sci 58:145-147

Katharios P, Papadakis IE, Prapas A, Dermon AC, Ampatzis K, Divanach P (2005) Mortality control of viral encephalopathy and retinopathy in $0+$ grouper Epinephelus marginatus after prolonged bath in dense Chlorella minutissima culture. Bull Eur Assoc Fish Pathol 25:28-31

Khaliluev MR, Shpakovskii GV (2013) Genetic engineering strategies for enhancing tomato resistance to fungal and bacterial pathogens. Russ J Plant Physiol 60:721-732

Kim JD (2006) Screening of cyanobacteria (blue-green algae) from rice paddy soil for antifungal activity against plant pathogenic fungi. Mycobiology 34:138-142

Köhl J, Kolnaar R, Ravensberg WJ (2019) Mode of action of microbial biological control agents against plant diseases: relevance beyond efficacy. Front Plant Sci 10:845

Kumar G, Sahoo D (2011) Effect of seaweed liquid extract on growth and yield of Triticum aestivum var. Pusa Gold J Appl Phycol 23:251-255

Kumar K, Verma PK (2013) Plant pathogen interactions: crop improvement under adverse conditions. In: Tuteja N, Gill SS (eds) Plant acclimation to environmental stress. Springer, New York, pp 433-459

Larqué-Saavedra A, Martín-Mex R, Nexticapan-Garcéz Á, VergaraYoisura S, Gutiérrez-Rendón M (2010) Effect of salicylic acid on the growth of tomato (Lycopersicon esculentum Mill.) seedlings. Rev Chapingo Ser Hort 16:183-187

Latin R, Tikhonova I, Rane K (1995) First report of bacterial canker of pepper in Indiana. Plant Dis 79:860

Lee SY, Khoiroh I, Vo DVN, Kumar PS, Show PL (2020) Techniques of lipid extraction from microalgae for biofuel production: a review. Environ Chem Lett 19:231-251

Lenteren JC, Bolckmans K, Köhl J (2018) Biological control using invertebrates and microorganisms: plenty of new opportunities. Biocontrol 63:39-59

Lu Y, Xu J (2015) Phytohormones in microalgae: a new opportunity for microalgal biotechnology. Trends Plant Sci 20:273-282

Marrez DA, Naguib MM, Sultan YY, Higazy AM (2019) Antimicrobial and anticancer activities of Scenedesmus obliquus metabolites. Heliyon 5:e01404

Masojídek J, Ranglová K, Rearte TA, Celis Plá PSM, Torzillo G, Silva Benavides AM et al (2021) Changes in photosynthesis, growth and biomass composition in outdoor Chlorella g120 culture 
during the metabolic shift from heterotrophic to phototrophic cultivation regime. Algal Res 56:102303

Mazur H, Konop A, Synak R (2001) Indole-3-acetic acid in the culture medium of two axenic green microalgae. J Appl Phycol 13:35-42

Meena M, Swapnil P, Zhehra A, Aamir M, Dubey MK, Goutam J, Upadhyay RS (2017) Beneficial microbes for disease suppression and plant growth promotion. In: Singh DP, Singh HB, Prabha R (eds) Plant-Microbe Interactions in Agro-Ecological Perspectives. Springer, Singapore, pp 395-432

Mendiola JA, Torres CF, Toré A, Martín-Álvarez PJ, Santoyo S, Arredondo BO, Señoráns FJ, Cifuentes A, Ibánez E (2007) Use of supercritical $\mathrm{CO}_{2}$ to obtain extracts with antimicrobial activity from Chaetoceros muelleri microalga. A correlation with their lipidic content. Eur Food Res Technol 224:505-510

Michalak I, Chojnacka K (2015) Algae as production systems of bioactive compounds. Eng Life Sci 15:160-176

Moustaine M, El Kahkahi R, Benbouazza A, Benkirane R, El Hassan A (2019) Potential of biological treatments for control of bacterial canker of tomato incited by Clavibacter michiganensis spp michiganensis in Morocco. Euras J Biol Sci 13:1481-1488

Nandi M, MacDonald J, Liu P, Weselowski B, Yuan ZC (2018) Clavibacter michiganensis subsp. michiganensis: bacterial canker of tomato, molecular interactions and disease management. Mol Plant Pathol 19:2036-2050

Natarajan C, Prasanna R, Gupta V, Dureja P, Nain L (2012) Characterization of the fungicidal activity of Calothrix elenkinii using chemical methods and microscopy. Appl Biochem Microbiol 48:51-57

Natarajan C, Gupta V, Kumar K, Prasanna R (2013) Molecular characterization of a fungicidal endoglucanase from the cyanobacterium Calothrix elenkinii. Biochem Genet 51:766-779

Navarro F, Forján E, Vázquez M, Toimil A, Montero Z, RuízDomínguez MdC, Garbayo I, Castaño MÁ, Vílchez C, Vega JM (2017) Antimicrobial activity of the acidophilic eukaryotic microalga Coccomyxa onubensis. Phycol Res 65:38-43

Navarro-López E, Ruíz-Nieto A, Ferreira A, Acién FG, Gouveia L (2020) Biostimulant potential of Scenedesmus obliquus grown in brewery wastewater. Molecules 25:664

Ördög V, Stirk WA, Lenobel R, Bancíŕová M, Strnad M, Van Staden J, Szigeti J, Németh L (2004) Screening microalgae for some potentially useful agricultural and pharmaceutical secondary metabolites. J Appl Phycol 16:309-314

Palaniyandi SA, Yang SH, Zhang L, Suh JW (2013) Effects of actinobacteria on plant disease suppression and growth promotion. Appl Microbiol Biotechnol 97:9621-9636

Prasanna R, Nain L, Tripathi R, Gupta V, Chaudhary V, Middha S, Joshi M, Ancha R, Kaushik BD (2008) Evaluation of fungicidal activity of extracellular filtrates of cyanobacteria - possible role of hydrolytic enzymes. J Basic Microbiol 48:186-194

Prasanna R, Chaudhary V, Gupta V, Babu S, Kumar A, Singh R, Singh YS, Nain L (2013) Cyanobacteria mediated plant growth promotion and bioprotection against Fusarium wilt in tomato. Eur J Plant Pathol 136:337-353

Raymaekers K, Ponet L, Holtappels D, Berckmans B, Cammue BPA (2020) Screening for novel biocontrol agents applicable in plant disease management - a review. Biol Control 144:104240

Renuka N, Guldhe A, Prasanna R, Singh P, Bux F (2018) Microalgae as multi-functional options in modern agriculture: current trends, prospects and challenges. Biotechnol Adv 36:1255-1273

Romanenko EA, Kosakovskaya IV, Romanenko PA (2015) Phytohormones of microalgae: biological role and involvement in the regulation of physiological processes. Pt I. Auxins, abscisic acid, ethylene. Int J Algae 17:275-289

Royston JP (1983) Some Techniques for assessing multivariate normality based on the Shapiro-Wilk W. Appl Stat 32:121-133
Santoro MV, Zygadlo J, Giordano W, Banchio E (2011) Volatile organic compounds from rhizobacteria increase biosynthesis of essential oils and growth parameters in peppermint (Mentha piperita). Plant Physiol Biochem 49:1177-1182

Schonlau M (2004) Visualizing non-hierarchical and hierarchical cluster analyses with clustergrams. Computat Statist 19:95-111

Sergeeva E, Liaimer A, Bergman B (2002) Evidence for production of the phytohormone indole-3-acetic acid by cyanobacteria. Planta 215:229-238

Singh JS (2014) Cyanobacteria: a vital bio-agent in eco-restoration of degraded lands and sustainable agriculture. Climate Change Environ Sustain 2:133-137

Singh SP, Häder DP, Sinha RP (2010) Cyanobacteria and ultraviolet radiation (UVR) stress: mitigation strategies. Ageing Res Rev 9:79-90

Singh JS, Kumar A, Rai AN, Singh DP (2016) Cyanobacteria: a precious bio-resource in agriculture, ecosystem, and environmental sustainability. Front Microbiol 7:529

Singh RS, Walia AK, Khattar JS, Singh DP, Kennedy JF (2017) Cyanobacterial lectins characteristics and their role as antiviral agents. Int J Biol Macromol 102:475-496

Stirk WA, Ördög V, Van SJ, Jäger K (2002) Cytokinins and auxin-like activity in Cyanophyta and microalgae. J Appl Phycol 14:215-221

Suárez-Estrella F, Arcos-Nievas MA, López MJ, Vargas-García MC, Moreno J (2013) Biological control of plant pathogens by microorganisms isolated from agro-industrial composts. Biol Control 67:509-515

Suárez-Estrella F, Jurado MM, López MJ, López-González JA, Moreno J (2019) Role of bacteria isolated from a plant waste-based compost producing bioactive substances in the control of bacterial spot syndrome caused by Xanthomonas campestris pv. vesicatoria. Biocatal Agric Biotechnol 20:101198

Svantesson T, Wallace J (2003) Tests for assessing multivariate normality and the covariance structure of mimo data. In: Acoustics, Speech, and Signal Processing. Proceedings. (ICASSP'03). 2003 IEEE International Conference onAcoustics, Speech and Signal Processing 4:656-659. https://doi.org/10.1109/ICASSP.2003. 1202728

Termorshuizen AJ, van Rijn E, Alabouvette C, Lagerlöf J, Paplomatas EJ, Rämert B, Ryckeboer J, Steinberg C, Zmora-Nahum S (2006) Suppressiveness of 18 composts against 7 pathosystems: variability in pathogen response. Soil Biol Biochem 38:2461-2477

Toribio AJ, Suárez-Estrella F, Jurado MM, López MJ, López-González JA, Moreno J (2020) Prospection of cyanobacteria producing bioactive substances and their application as potential phytostimulating agents. Biotech Rep 26:e00449

Toribio AJ, Jurado MM, Suárez-Estrella F, López MJ, López-González JA, Moreno J (2021) Seed biopriming with cyanobacterial extracts as an eco-friendly strategy to control damping off caused by Pythium ultimum in seedbeds. Microbiol Res 248:126766

Umesha S (2006) Occurrence of bacterial canker in tomato fields of Karnataka and effect of biological seed treatment on disease incidence. Crop Prot 25:375-381

Volk RB, Furkert FH (2006) Antialgal, antibacterial and antifungal activity of two metabolites produced and excreted by cyanobacteria during growth. Microbiol Res 161:180-186

Weller DM, Raaijmakers JM, Gardener BBM, Thomashow LS (2002) Microbial populations responsible for specific soil suppressiveness to plant pathogens. Annu Rev Phytopathol 40:309-348

Zucconi F, Pera A, Forte M, De Bertoldi M (1981) Evaluating toxicity of immature compost. Biocycle 22:54-57

Publisher's note Springer Nature remains neutral with regard to jurisdictional claims in published maps and institutional affiliations. 